\title{
Isolation and Identification of Actinomycetes Associated with Moss on the Surface of the Borobudur Temple Stone
}

\author{
Ade Lia Putri $^{1}$, Debora Christin Purbani ${ }^{1}$, Atit Kanti ${ }^{1}$, Mia Kusmiati ${ }^{1}$, Moh. Habibi ${ }^{2}$ \\ ${ }^{1}$ Research Centre for Biology, LIPI, Indonesia \\ ${ }^{2}$ Borobudur Conservation Office, Indonesia \\ *Email: adelia.rikardi@gmail.com
}

Submitted: 1 August 2019. Revised: 11 January 2020. Accepted: 20 March 2020

\begin{abstract}
Mosses growing on the surface of the Borobudur Temple will affect the aesthetic value of the temple. Interaction between moss and actinomycetes may trigger the growth of moss that can cause an increase in biodeterioration of stone. The purpose of this study was to isolate and identify the actinomycetes associated with moss on the surface of decayed stone of Borobudur Temple as well to assess their ability for phosphate solubilizing. Actinomycetes were isolated using serial dilution method and were identified based on 16S rRNA gene sequences. A total of 37 actinomycetes were isolated from three sampling sites. The isolates found belong to five genera (Gordonia, Microbacterium, Micromonospora, Nocardia, and Streptomyces) and distributed among four families (Microbacteriaceae, Micromonosporaceae, Nocardiaceae, and Streptomycetaceae). Isolates of actinomycetes composed of 19 Streptomyces Group and 18 Rare Actinomycetes Group. Nineteen isolates (51.35\%) were identified as genus Streptomyces. Seventeen isolates (45.94\%) showed abilities to release soluble phosphate and most of the isolates belong to the genus Streptomyces. The isolates have been collected will be deposited to Indonesian Culture Collection (InaCC) to enrich the collection of actinomycetes from ancient stone in Indonesia and will be used as a source of reference material research, taxonomic, or as a source for further study.
\end{abstract}

Keywords: Actinomycetes; Borobudur Temple; Moss; Stone; Soluble Phosphate

How to Cite: Putri, A. L., Purbani, D. C., Kanti, A., Kusmiati, M., \& Habibi, M. (2020). Isolation and Identification of Actinomycetes Associated with Moss on the Surface of the Borobudur Temple Stone. Biosaintifika: Journal of Biology \& Biology Education, 12 (1), $10-20$

DOI: http://dx.doi.org/10.15294/biosaintifika.v12i1.20334

\section{INTRODUCTION}

Borobudur Temple is one of the Buddhist monuments located in Magelang Regency in the central part of Java, Indonesia (Hermawan, et al.,, 2016). Borobudur Temple was composed using andesite materials (Haldoko et al., 2014). The andesite stones of Borobudur Temple have different characteristics (hardness, porosity, and alkalinity) that affect its susceptibility to biodeterioration (Haldoko et al., 2014). Degradation of the ancient stone may be caused by the growth and the activity of living organisms such as bacteria (including actinomycetes), fungi, archaea, algae, mosses, and lichens (Purawijaya \& Priyantika, 2013). Characteristic of the stone and the environmental condition influence the extent of microorganism colonization and biodeterioration process. High rainfall will increase the moisture of the stone, thus trigger the growth of microorganisms. Many studies have been reported that microorganisms were found on the surface of stone monument (Keshari \& Adhikary, 2014; Pinheiro et al., 2018). Some microorganisms may grow on the surface (epilithic) or may penetrate the rock pore system and grow in the crack and pores of the stone (endolithic) (Gaylarde, Gaylarde, \& Neilan, 2012).

Mosses are one of most found organism on the surface of Borobudur Temple. Although mosses have been reported not to be the main cause of deterioration on Borobudur stones (Purawijaya \& Priyantika, 2013), but if mosses grow on a large scale on the surface of stone, it will affect the aesthetic value of the Borobudur Temple. Therefore, it is important to preserve the Borobudur Temple from further natural destruction for our future generation. Interaction between moss and other endolithic microorganisms such as actinomycetes can enhance the rate of biodegradation.

Actinomycetes are Gram-positive bacteria with high Guanine and Cytosine content. Actinomycetes are divided into two groups, the Streptomyces Group and Rare Actinomycetes Group (non-Streptomyces strains). Actinomycetes are interesting to study because of their ability to produce various secondary metabolites and to form a mycelium that can grow in crack and pores of the stone (Abdulla et al. 2008). Actinomycetes have the ability to utilize organic matter present in stone as a carbon source. Actinomycetes that are associated with moss on the surface of stone may trigger the growth of moss and cause an increase in biodeterioration of stone. Actinomycetes may have an important role in providing nutrients for moss growth. Actinomycetes have been reportedly isolated from various types of historical monuments (Abdelhafez, El-Wekeel, Ramadan, \& Abed-Allah, 2012; H. 
Li, Lan, Katayama, Gu, \& Wang, 2010; Q. Li, Zhang, He, \& Yang, 2016; Pinheiro et al., 2018).

Study about actinomycetes isolated from Borobudur Temple stone has never been reported before, especially regarding its association with moss that overgrown the stone of Borobudur Temple. Therefore, the purpose of this study was to isolate and identify the actinomycetes associated with moss on the surface of the stone of Borobudur Temple and their ability in phosphate solubilizing. The isolation and identification of actinomycetes from decayed stone is important not only to understand their role in decayed stone of Borobudur Temple, but is also as a source for taxonomical study. The actinomycetes have been collected will be deposited to Indonesian culture collection (InaCC) to enrich the collection of actinomycetes from ancient stone in Indonesia. The isolates will be used as a source of reference material research, taxonomic, or as source for further research to the evaluation the effect of these actinomycetes to trigger the growth of mosses and to the evaluation their effect to cause damage to the stone.

\section{METHODS}

\section{Samples Collection}

The samples of mosses were collected from the surface of decayed stone of Borobudur Temple. The samples were collected using a spatula and put into plastic bags (Figure 1). The samples were obtained from three different tiers of Borobudur temple. They were collected from the base of the temple (A18BR1), the second tier of the temple (A18BR2), and top of temple (stupa) (A18BR3).

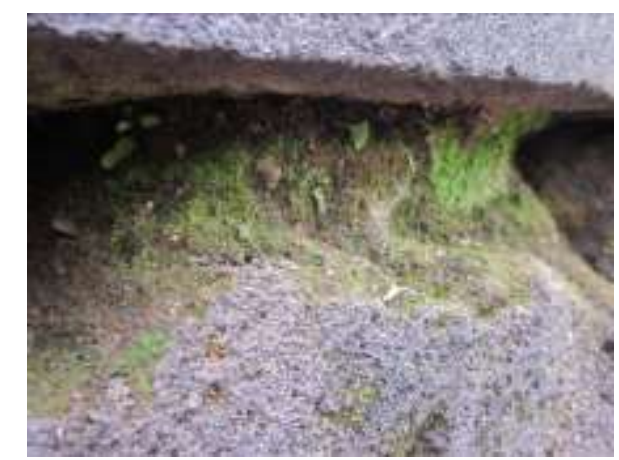

Figure 1. The stone overgrown with moss

\section{Isolation of Actinomycetes Associated With Moss on the Surface of Decayed Stone of Borobudur Temple}

Actinomycetes were isolated using serial dilution method. One gram of each sample was suspended in $10 \mathrm{~mL}$ sterile distilled water. The suspension was homogenized using vortex for 10 minutes and was shaken at room temperature using orbital shaker at $200 \mathrm{rpm}$ for 15 minutes. One $\mathrm{ml}$ aliquot from the suspension was transferred to a test tube containing 9 $\mathrm{ml}$ of sterile distilled water and was mixed well. The suspension was then diluted with sterile water up to $10^{-6}$. About $100 \mu \mathrm{L}$ solution from each dilution was pipetted and was spread onto the plates of isolation medium. The medium used for isolation were Humic Acid Agar (HVA), and Actinomycetes Isolation Agar (AIA) supplemented with nalidixic acid $(20 \mathrm{mg} / \mathrm{L})$ and cycloheximide $(50 \mathrm{mg} / \mathrm{L})$. The plates were then incubated at $30^{\circ} \mathrm{C}$ for 7-14 days. Isolates of actinomycetes that have grown well and have different morphological characteristic were purified on Yeast Starch Agar (YSA) medium. The pure culture was kept in cryotube containing $10 \%$ glycerol at $-80^{\circ} \mathrm{C}$ for further studies.

\section{Molecular Identification of Actinomycetes and Phylogenetic Tree Analysis}

Total genomic DNA was extracted using a modified method of Franco-Correa et al. (2010). The isolates of actinomycetes used as DNA template were prepared on YSA agar plate for seven days. The biomass of actinomycetes was then harvested by scraping off the mycelia and spore from a colony of actinomycetes from this media. The mycelia and spore were then put into microtube and incubated for overnight at $-20^{\circ} \mathrm{C}$. After incubation, the mycelia and spore of actinomycetes were cleaned three times with distilled water (500 ul), and the samples were dispersed in lysis solution (Franco-Correa et al., 2010). Furthermore, partial 16S rRNA gene sequence was determined from the PCR-amplification fragment. The fragment of 16S rRNA gene sequence was amplified using universal primer 27F (5' AGAGTTTGATCCTGGCTCAG 3') and 1492R (5' GGTTACCTTGTTACGACTT 3'). The PCR condition consisted of an initial denaturation at $94^{\circ} \mathrm{C}$ for 1 minute followed by 30 cycles of amplification (denaturation at $95^{\circ} \mathrm{C}$ for 30 seconds, annealing at $50^{\circ} \mathrm{C}$ for 30 seconds, and elongation at $72^{\circ} \mathrm{C}$ for 1 minute 30 seconds) (Putri, Lisdiyanti, \& Kusmiati, 2018). Then the 16S rRNA gene fragment was sequenced by Macrogen ${ }^{\circledR}$. The raw sequencing data were analyzed using Cromaspro program version 1.6. The complete fragments of $16 \mathrm{~S}$ rRNA gene sequenced were compared with other sequences in the EzTaxon-e server (Kim et al., 2012). Furthermore, the 16S rRNA gene sequenced were aligned with the reference sequence of known species in a genus using CLUSTAL W. The phylogenetic tree of nucleotide sequences was constructed using the neighbor-joining distances method. The confidence of the clusters was assessed using a bootstrap analysis with 1000 replications. 


\section{In Vitro Screening of Phosphate-Solubilizing Acti- nomycetes}

The isolates were cultivated on the minimal medium based on the Pikovskaya (PVK) medium. The medium contained $5 \mathrm{~g} / \mathrm{L}$ Ca3PO4; $0.5 \mathrm{~g} / \mathrm{L}$ yeast extract ; 0,01 g/L FeCl3.6H2O; $10 \mathrm{~g} / \mathrm{L}$ glucose; 0,2 g/L $\mathrm{KCl} ; 0,1 \mathrm{~g} / \mathrm{l} \mathrm{MgSO} 4.7 \mathrm{H} 2 \mathrm{O} ; 0,01 \mathrm{~g} / \mathrm{L}$ MnSO4.H2O; $0,5 \mathrm{~g} / \mathrm{L}$ (NH4)2.SO4; and $18 \mathrm{~g} / \mathrm{L}$ agar with $\mathrm{pH} 7$ (Khan, Zaidi, \& Musarrat, 2014). The actinomycetes were streaked (about $6 \mathrm{~mm}$ of diameter) on the surface of PVK medium then incubated at $30^{\circ} \mathrm{C}$ for 7-14 days and observed for halo formation. The positive result showed the formation of clear zones around the colony of actinomycetes on the culture plate.

\section{RESULTS AND DISCUSSION}

\section{Isolation of Actinomycetes Associated with Moss on the Surface of Decayed Stone of Borobudur Temple}

A total of 37 actinomycetes were isolated from three samples collection (Figure 2). The AIA medium supported higher count and more diversity of actinomycetes than HVA medium (Figure 3). The number of actinomycetes isolates varied in the three samples. The highest number of actinomycetes isolated from decayed stones at the third tier or Stupa (16 isolates). The pure isolates than were kept in cryotube with $10 \%$ glycerol at $-80^{\circ} \mathrm{C}$. Morphological observation obtained that actinomycetes had diverse colony colour. The colours observed were brown, black, yellow, pink, and white. Actinomycetes found from moss on the surface of decayed stone of Borobudur Temple were quite diverse. Abdulla et al. (2008) reported that the number and variation species of actinomycetes isolated from decay stone is higher than the sound stone. This is probably due to the nutrients available in decayed stoned are likely to be complex organic acid remains, the actinomycetes easier to utilize the nutrient a wide range of more complex and recalcitrant polymers such as polysaccharides and lignocellulose (Saini, Aggarwal, Sharma, \& Yadav, 2015; Yeager et al., 2017). Abdulla et al. (2008) found 56 species of actinomycetes belonging to 15 genera from decayed stone. Haldoko et al. (2014) reported that the different characteristic of Borobudur temple stone causing differences in the level of damage and decay occurs.

\section{Identification of Actinomycetes Based on $16 \mathrm{~S}$ rRNA Gene Sequence}

The isolates of actinomycetes were divided into two groups (Streptomyces Group and Rare Actinomycetes Group). Streptomyces Group and Rare Actinomycetes Group were identified by analysis of par- tial sequence of their 16S rRNA gene sequence and compared with known species in public database. A total of 19 isolates $(51.35 \%)$ have belonged to Streptomyces Group, and 18 isolates $(48.65 \%)$ have belonged to Rare Actinomycetes Group . The isolates were identified belong to five genera (Gordonia, Microbacterium, Micromonospora, Nocardia, and Streptomyces) and distributed among four families (Microbacteriaceae, Micromonosporaceae, Nocardiaceae, and Streptomycetaceae).

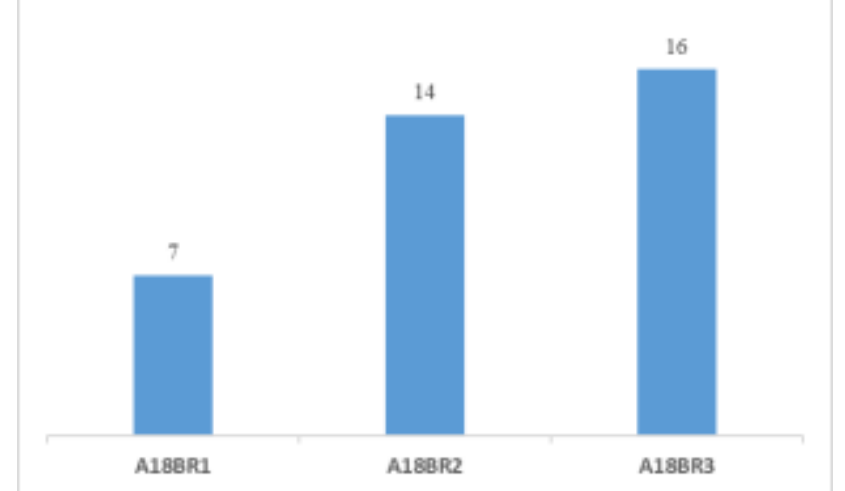

Figure 2. Number of actinomycetes isolated from moss on decayed stones of Borobudur Temple

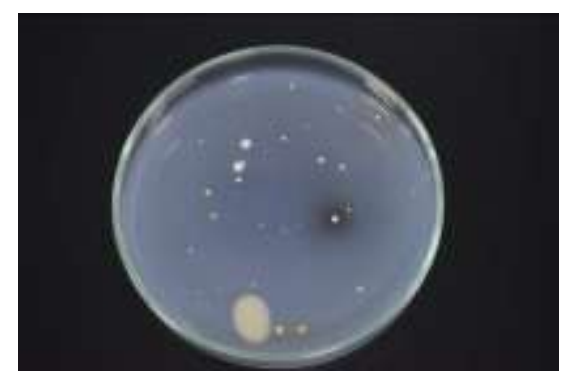

Figure 3. Actinomycetes growth on AIA media plate for seven days and incubated at $30^{\circ} \mathrm{C}$

Based on molecular characteristic, the isolates of Streptomyces Group included under genus Streptomyces. While, the isolates of Rare Actinomycetes Group included under four genera (Microbacterium, Micromonospora. Gordonia, and Nocardia) (Table 1). The most dominant Group of Rare Actinomycetes belong to genus Micromonaspora in which nine isolates (Table 1). A large number of actinomycetes isolated from a decayed stone of Borobudur Temple belong to genus Streptomyces $(51,35 \%)$. This is possible because genus of Streptomyces is widely distributed. Streptomyces are widely distribution in environment and they grow quickly under conventional culture condition. By contrast, Rare Actinomycetes Group is generally characterized by slow growth and small colony (Hop et al., 2011). Fifty per cent of the actinomycetes isolated from decayed and sound stone samples taken from a tomb site at Tell Basta, Zagazig City, Egypt, was identified as Streptomyces (Abdulla et al., 2008). 
Table 1. Diversity of actinomycetes associated with moss on decayed stones of Borobudur Temple

\begin{tabular}{lllc}
\hline Group & Family & Genus & Number of isolates \\
\hline Streptomyces & Streptomycetaceae & Streptomyces & 19 \\
Rare Actinomycetes & Microbacteriaceae & Microbacterium & 7 \\
& Micromonosporaceae & Micromonospora & 9 \\
& Nocardiaceae & Gordonia & 1 \\
& & Nocardia & 1 \\
\hline Total & & 37 \\
\hline
\end{tabular}

Table 2. The Streptomyces Group isolated from moss on the surface of decayed stone of Borobudur Temple

\begin{tabular}{lllc}
\hline Isolate code & Closest type strain & Similarity (\%) \\
\hline A18BR 1(2) & Streptomyces chartreusis & NBRC 12753(T) & 99.25 \\
A18BR 1(10) & Streptomyces griseoluteus & NBRC 13375 & 98.63 \\
A18BR 1(11) & Streptomyces termitum & NBRC 13087(T) & 99.43 \\
A18BR 2(6) & Streptomyces zhihengii & YIM T102(T) & 99.71 \\
A18BR 2(9) & Streptomyces polychromogenes & NBRC 13072(T) & 99.77 \\
A18BR 2(12) & Streptomyces avellaneus & NBRC 13451(T) & 99.63 \\
A18BR 2(13) & Streptomyces polychromogenes & NBRC 13072 & 99.77 \\
A18BR 3(5) & Streptomyces bungoensis & DSM 41781(T) & 99.70 \\
A18BR 3(6) & Streptomyces griseoruber & NRRL B-1818(T) & 99.92 \\
A18BR 3(8) & Streptomyces tritici & NRRL S-87 & 98.85 \\
A18BR 3(9) & Streptomyces bungoensis & DSM 41781(T) & 99.68 \\
A18BR 3(13) & Streptomyces tritici & KY744943 & 98.79 \\
A18BR 3(14) & Streptomyces griseoluteus & NBRC 13375 & 98.63 \\
A18BR 3(15) & Streptomyces neopeptinius & KNF 2047(T) & 99.19 \\
A18BR 3(17) & Streptomyces violaceorectus & NBRC 13102(T) & 98.74 \\
A18BR 3(18) & Streptomyces polychromogenes & NBRC 13072(T) & 99.77 \\
A18BR 3(19) & Streptomyces echinatus & NBRC 12763(T) & 98.96 \\
A18BR 3(20) & Streptomyces polychromogenes & NBRC 13072(T) & 99.76 \\
A18BR 3(21) & Streptomyces wuyuanensis & CGMCC 4.7042(T) & 100.00 \\
\hline
\end{tabular}

A total of 19 isolates belong to the genus Streptomyces distributed among twelve species (Table 2). The isolates contained between $98.63-100 \%$ DNA homology to their closest type strain. A total of 18 isolates belong to Rare Actinomycetes Group distributed among eleven species (Table 3). The isolates contained between $98.08-100 \%$ DNA homology to their closest type strain. The dominant Group of Streptomyces belonged to the species Streptomyces polychromogenes (Table 2) and the dominant Group of Rare Actinomycetes belong to species Micromonospora maritima (Table 3 ).

The molecular identification was supported by the phylogenetic tree analysis based on a neighbourjoining tree. The 37 isolates sorted into four main clusters and the isolates confirmed were affiliation to four actinomycetes families (Microbacteriaceae, Micromonosporaceae, Nocardiaceae, and Streptomycetaceae). Nineteen isolates were affiliated within the clustered of the family Streptomycetaceae (genus Streptomyces) (Figure 4). Seven isolates were affiliated within the cluster of the family Microbacteriaceae (genus Microbacterium) (Figure 5). Nine isolates were affiliated within the cluster of the family Micromonasporaceae (genus Micromonaspora) (Figure 6). Two isolates were affiliated within the cluster of family Nocardiacea (genera Nocardia and Gorania) (Figure 6).

Some of the isolates showed different branch with other known species of the nearest genus on each cluster such as isolates (A18BR 3(13), A18BR 3(8), A18BR 3(17), and A18BR 3(15)) showed branch difference with the most closely related Streptomyces species (Figure 4). The isolate A18BR 2(15) also showed different branch from its nearest Microbacterium species neighbours (Figure 5). Further, a taxonomical study of the isolates compare with known species is needed. 
Table 3. The Rare Actinomycetes Group isolated from moss on the surface of decayed stone of Borobudur Temple

\begin{tabular}{lllc}
\hline Isolate code & Closest type strain & Similarity (\%) \\
\hline A18BR 1(1) & Micromonospora maritima & D10-9-5(T) & 100.00 \\
A18BR 1(3) & Nocardia thailandica & NBRC 100428(T) & 98.08 \\
A18BR 1(6) & Micromonospora maritima & D10-9-5 & 100.00 \\
A18BR 1(8) & Micromonospora sediminicola & DSM 45794(T) & 100.00 \\
A18BR 2(1) & Gordonia hongkongensis & HKU50(T) & 100.00 \\
A18BR 2(2) & Microbacterium arborescens & DSM 20754 & 98.86 \\
A18BR 2(3) & Microbacterium arborescens & DSM 20754(T) & 99.01 \\
A18BR 2(4) & Microbacterium invictum & DC-200(T) & 98.81 \\
A18BR 2(5) & Microbacterium flavescens & DSM 20643(T) & 98.83 \\
A18BR 2(7) & Micromonospora maritima & D10-9-5(T) & 100.00 \\
A18BR 2(8) & Micromonospora mangrovi & 2803GPT1-18(T) & 99.47 \\
A18BR 2(10) & Micromonospora maritima & D10-9-5(T) & 100.00 \\
A18BR 2(11) & Micromonospora mangrovi & 2803GPT1-18(T) & 99.18 \\
A18BR 2(15) & Microbacterium aureliae & JF-6(T) & 98.50 \\
A18BR 3(1) & Microbacterium ginsengisoli & DSM 18659(T) & 99.01 \\
A18BR 3(3) & Microbacterium ginsengisoli & DSM 18659(T) & 98.97 \\
A18BR 3(7) & Micromonospora halophytica & DSM 43171(T) & 99.41 \\
A18BR 3(11) & Micromonospora maritima & D10-9-5 & 100.00 \\
\hline
\end{tabular}

Some species in this study have been reported successful isolated from various samples such as soil, plant, pollutant water, coastal, sea sediment, or human body (Carro et al., 2018; Luo, Hu, Peng, Zhang, \& Wang, 2015; Wibberg et al., 2018; Klymyshin et al., 2013; Bourbour, Keikha, \& Faghri, 2018; Tsang et al., 2016; Chen, Tang, Mori, \& Wu, 2012; Kumar et al., 2016; Xie et al., 2016a). The isolates have been reported as a source of several secondary metabolites were Micromonospora halophytica (Carro et al., 2018), Microbacterium ginsengisoli (Palaniappan et al., 2010), Streptomyces avellaneus (RamirezRodriguez et al., 2018), Streptomyces bungoensis (Michael et al., 2017), Streptomyces chartreusis (Wibberg et al., 2018), Streptomyces echinatus (Klymyshin et al., 2013), Streptomyces griseoluteus (Luo et al., 2015), Streptomyces griseoruber (Wang, Peng, Zhang, Hui, \& Hu, 2014), Streptomyces neopeptinius (Goudjal et al., 2016), Streptomyces polychromogenes (Mitsukura, Sakamoto, Kubo, Yoshida, \& Nagasawa, 2010), Streptomyces termitum (Sales et al., 2017), and Streptomyces violaceorectus (Fallah, 2018).

Two species were reported to cause diseases in human: they were Gordonia hongkongensis and $\mathrm{No}$ - cardia thailandica (Bourbour, Keikha, \& Faghri, 2018; Tsang et al., 2016). Both of the isolates belonged to family Nocardiaceae. Some species from this study also have been reported successfully isolated from coastal areas and mangroves sediments. The isolates were Micromonospora sediminicola isolated from marine sediment (Pittayakhajonwut et al., 2012), Microbacterium aureliae isolated from Aurelia auri$\mathrm{ta}$, the moon jellyfish (Kumar et al., 2016), Micromonospora mangrove (Xie et al., 2016a), and Micromonospora maritime (Xie et al., 2016b) isolated from mangrove sediment. Chemical compounds contained in the decayed rock of Borobudur Tempel and many people visited this Temple may influences the genus/species of actinomycetes were founded. Haldoko et al. (2014) reported that the stone material of Borobudur Temple containing silicate $\left(\mathrm{SiO}_{2}\right)$, aluminium $\left(\mathrm{Al}_{2} \mathrm{O}_{3}\right)$, iron $\mathrm{Fe}_{2} \mathrm{O}_{3},(\mathrm{FeO})$, calcium $(\mathrm{CaO})$, magnesium $(\mathrm{MgO})$, sodium $\left(\mathrm{Na}_{2} \mathrm{O}\right)$, and potassium $\left(\mathrm{K}_{2} \mathrm{O}\right)$. The stone overgrown with moss has higher potassium content, while $\mathrm{SiO} 2$ content of stone overgrown with moss is lower than a stone that is not overgrown with moss (Haldoko et al., 2014). 


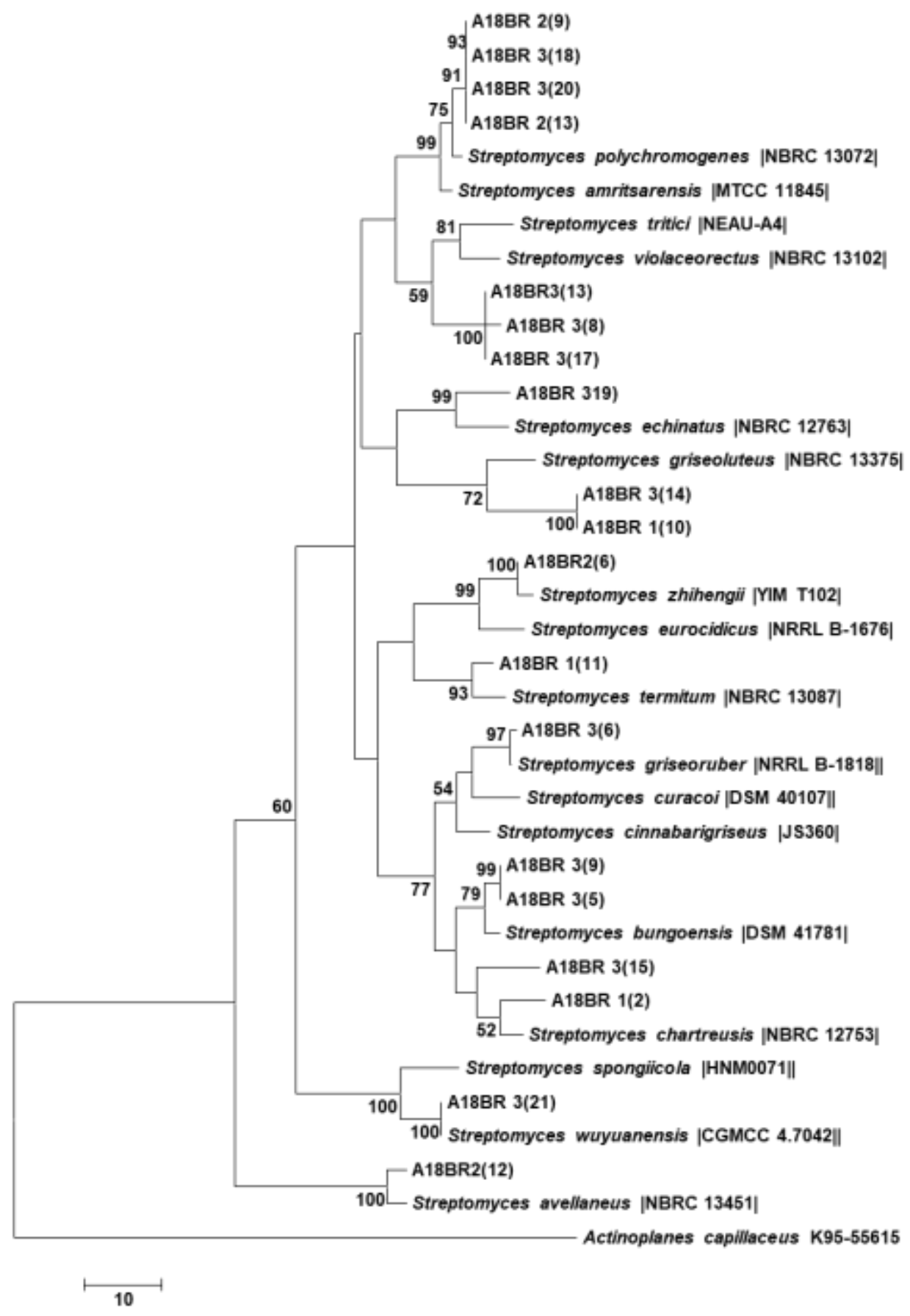

Figure 4. Neighbour-joining tree based on 16S rRNA gene sequences of actinomycetes isolated from mosses on the surface of decayed stone of Borobudur Temple and their closely related type strain within the family Streptomycetaceae. .Bootstrap values are expressed as percentages 1000 replications. Bootstrap values $>50$ are shown at branch points. The bar represents ten substitutions per nucleotide position. Actinoplanes capillaceus K95-55615 was used as an outgroup sequence 


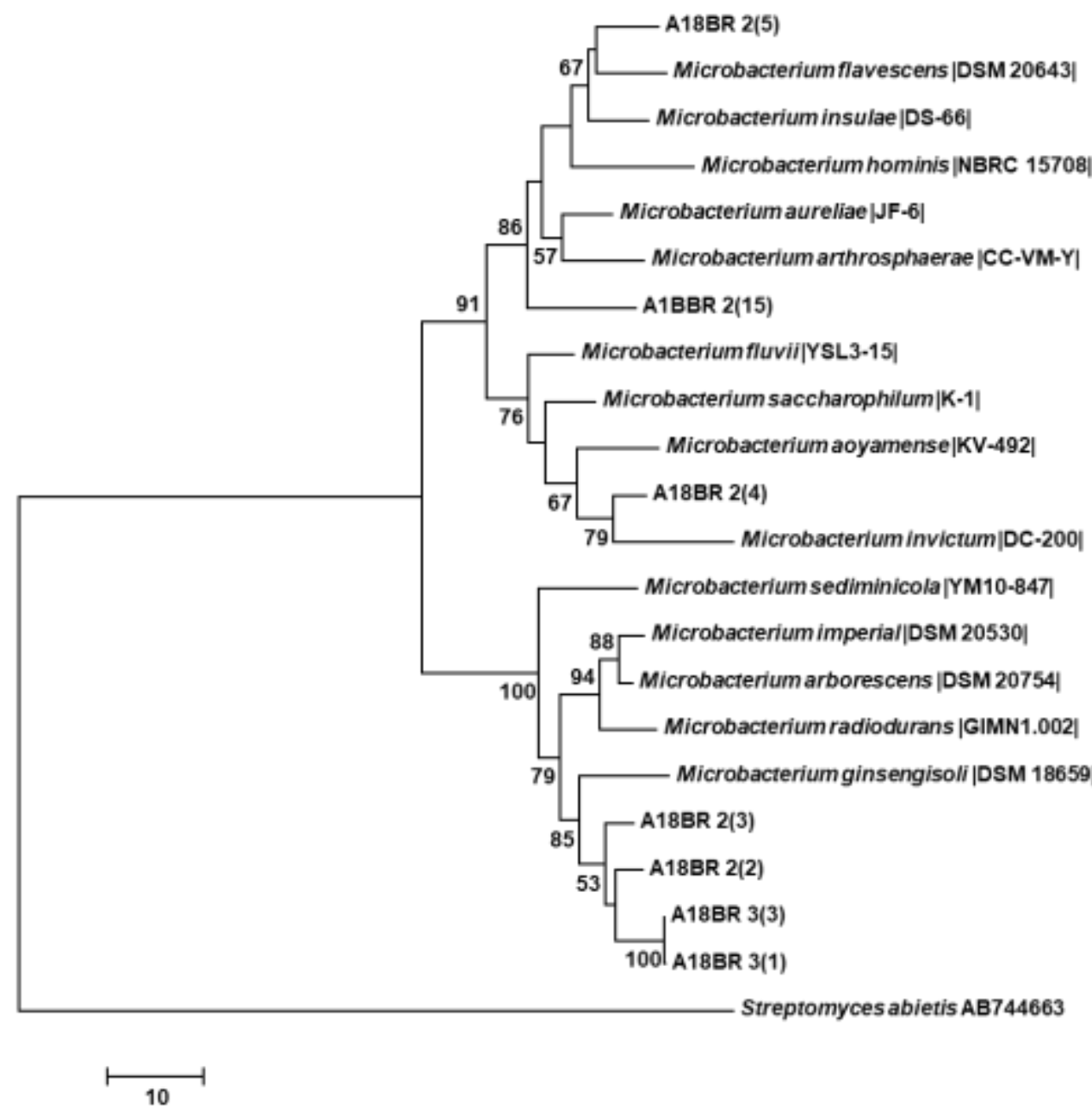

Figure 5. Neighbour-joining tree based on 16S rRNA gene sequences of actinomycetes isolated from mosses on the surface of decayed stone of Borobudur Temple and their closely related type strain within the family Microbacterium. Bootstrap values are expressed as percentages 1000 replications. Bootstrap values $>50$ are shown at branch points. The bar represents ten substitutions per nucleotide position. Streptomyces abietis $\mathrm{AB} 744663$ was used as an outgroup sequence

\section{Screening of Phosphate-solubilizing Actinobacte- ria}

Out of 37 isolates, seventeen isolates $(45.94 \%)$ showed abilities to release soluble phosphate. The positive result was indicated by the formation of clear zones around the colony of actinomycetes on the PVK medium (Figure 7). Phosphate was released in a range of 7-27.5mm (Table 4). Most of the isolates that have abilities to release soluble phosphate belong to genus Streptomyces (88.24\%). Only two isolates belong to the Rare Actinomycetes Group, A18BR 1(3) and A18BR 2(15). Both isolates were isolated from the decayed stone from the base of Borobudur temple. The isolates had similarity with Nocardia thailandica and Microbacterium aureliae based on 16S rRNA gene sequencing (Table 5). The isolates of actinomycetes have potential in dissolving phosphate. The formation of an inhibition zone proves that the actinomycetes isolate can dissolve inorganic phosphate in the form of tricalcium phosphate $\left(\mathrm{Ca}_{3}\left(\mathrm{PO}_{4}\right)_{2}\right)$ that is contained in the media. The formation of clear zones can also be caused by the production of organic acid by actinomycetes (Sharma, Sayyed, Trivedi, \& Gobi, 2013). Hamdali et al. (2008) reported that total of 55 isolates of actinomycetes isolated from three different Moroccan phosphate mining centres were able to soluble rock phosphate in the synthetic minimum medium (Hamdali et al., 2008). The result indicated that a large number of actinomycetes were isolated from a decayed stone of Borobudur Temple potential in dissolving phosphate. The isolates may trigger the growth of mosses on Borobudur stone, and they may cause an increase in biodeterioration of Borobudur Temple stone. 


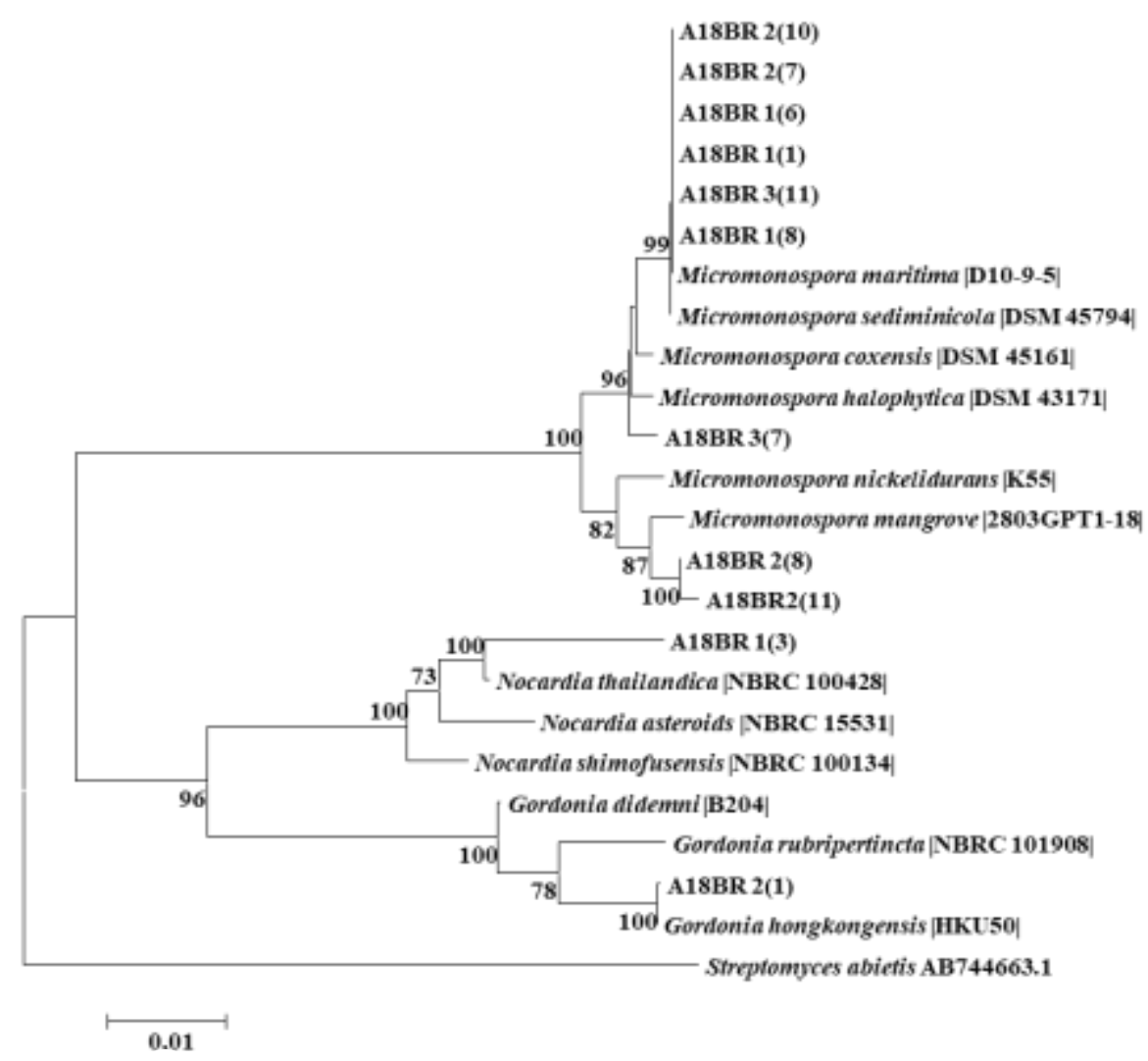

Figure 6. Neighbour-joining tree based on 16S rRNA gene sequences of actinomycetes isolated from mosses on the surface of decayed stone of Borobudur Temple and their closely related type strain within the family Micromonasporaceae and the family Nocardiaceae. Bootstrap values are expressed as percentages 1000 replications. Bootstrap values $>50$ are shown at branch points. The bar represents 0.01 substitutions per nucleotide position. Streptomyces abietis AB744663 was used as an outgroup sequence

Table 4. Phosphate solubilization actinomycetes isolated from moss on the decayed stone of Borobudur Temple

\begin{tabular}{llc}
\hline Isolates code & Species & Hallo zones index (mm) \\
\hline A18BR1(2) & Streptomyces chartreusis & 15 \\
A18BR1(3) & Nocardia thailandica & 12 \\
A18BR1(10) & Streptomyces griseoluteus & 11.5 \\
A18BR2(9) & Streptomyces polychromogenes & 14.5 \\
A18BR2(12) & Streptomyces avellaneus & 11 \\
A18BR2(15) & Microbacterium aureliae & 14 \\
A18BR3(5) & Streptomyces bungoensis & 20 \\
A18BR3(6) & Streptomyces griseoruber & 18 \\
A18BR3(8) & Streptomyces tritici & 9.5 \\
A18BR3(9) & Streptomyces bungoensis & 16 \\
A18BR3(13) & Streptomyces tritici & 10 \\
A18BR3(14) & Streptomyces griseoluteus & 18 \\
A18BR3(15) & Streptomyces neopeptinius & 15.5 \\
A18BR3(17) & Streptomyces violaceorectus & 10.7 \\
A18BR3(19) & Streptomyces echinatus & 27.5 \\
A18BR3(20) & Streptomyces polychromogenes & 7 \\
A18BR3(21) & Streptomyces wuyuanensis & 8 \\
\hline
\end{tabular}




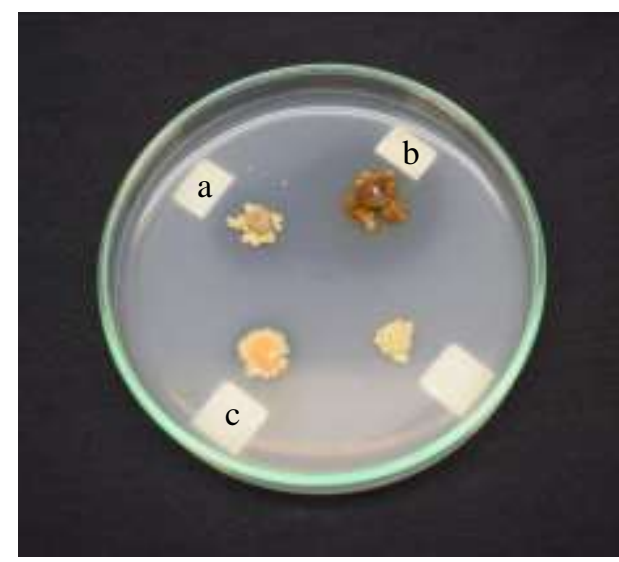

Figure 7. Zone of phosphate solubilisation around the colony growth of isolates a) A18BR 3(8), b) A18BR 3(5) and c) A18BR 3(20) on Pikovskaya's agar plate medium

The isolation and characterization of these actinomycetes from a decayed stone of Borobudur Temple is important not only to understand their role on the stone but also for taxonomical study of the actinomycetes from a decayed stone of Borobudur Temple. The isolates will be deposited to InaCC to enrich the collection of InaCC and to further research. Isolates showed different branched with others known of the species on the phylogenetic tree that taxonomic interest needs further study. On the other hand, the effect of the isolates triggers growth of mosses and their cause an increase in biodeterioration of Borobudur temple stones need further studied.

\section{CONCLUSION}

The environment condition and characteristic of stone of Borobudur Temple supported the present of actinomycetes at different tiers of Borobudur temple. The highest number of actinomycetes were isolated from decayed stones at the third tier (Stupa). The kind of medium used for isolation of actinomycetes may affect the number and variation of actinomycetes found. AIA medium support higher number and diversity of actinomycetes than HVA medium. The isolates of actinomycetes found belong to five genera (Gordonia, Microbacterium, Micromonospora, Nocardia, and Streptomyces). About $51.35 \%$ of the actinomycetes isolates belong to genus Streptomyces. The actinomycetes isolates were capable of releasing soluble phosphate under laboratory test $(45.94 \%)$, and most of them were identified as Streptomyces.

\section{ACKNOWLEDGEMENT}

Research was funded by DIPA Research Centre for Biology (2018), LIPI. The author also would like to thank Borobudur Conservation Office Borobudur for giving permission and help during the samples collection, as well as Gita Azizah Putri from Research Centre for Biology, Indonesian Institute of Sciences for help during the research period in the laboratory.

\section{REFERENCES}

Abdelhafez, A. A. M., El-Wekeel, F. M., Ramadan, E. M., \& Abed-Allah, A. A. (2012). Microbial deterioration of archaeological marble: Identification and treatment. Annals of Agricultural Sciences, 57(2), 137-144.

Abdulla, H., May, E., Bahgat, M., \& Dewedar, A. (2008). Characterisation of Actinomycetes Isolated from Ancient Stone and Their Potential for Deterioration. Polish Journal of Microbiology, 57(3), 213-220.

Bourbour, S., Keikha, M., \& Faghri, J. (2018). First report of the isolation of Nocardia thailandica from the bronchoalveolar lavage of a patient in Iran. Iranian Journal of Medical Sciences, 43(5), 560563.

Carro, L., Kim, K. E., Woyke, T., Montero-Calasanz, M. del C., Smith, D. L., Goodfellow, M., Peluso, P. (2018). Genome-based classification of micromonosporae with a focus on their biotechnological and ecological potential. Scientific Reports, $8(1), 1-23$.

Chen, W. M., Tang, Y. Q., Mori, K., \& Wu, X. L. (2012). Distribution of culturable endophytic bacteria in aquatic plants and their potential for bioremediation in polluted waters. Aquatic Biology, 15(2), 99-110.

Fallah, K. N. (2018). The Effects of Combination Antibiotic Therapy on Methicillin-Resistant Staphylococcus aureus. Health Science Scholars Honors Program in the College of Natural Sciences at The University of Texas at Austin.

Franco-Correa, M., Quintana, A., Duque, C., Suarez, C., Rodríguez, M. X., \& Barea, J.-M. (2010). Evaluation of actinomycete strains for key traits related with plant growth promotion and mycorrhiza helping activities. Applied Soil Ecology, 45(3), 209-217.

Gaylarde, C. C., Gaylarde, P. M., \& Neilan, B. A. (2012). Endolithic phototrophs in built and natural stone. Current Microbiology, 65(2), 183-188.

Goudjal, Y., Zamoum, M., Meklat, A., Sabaou, N., Mathieu, F., \& Zitouni, A. (2016). Plant-growthpromoting potential of endosymbiotic actinobacteria isolated from sand truffles (Terfezia leonis Tul.) of the Algerian Sahara. Annals of Microbiology, 66(1), 91-100.

Haldoko, L. A., Muhammad, R., \& Purwoko, W. (2014). Karakteristik Batu Penyusun Candi 
Borobudur. Jurnal Konservasi Cagar Budaya Borobudur, 8(1), 38-47.

Hamdali, H., Bouizgarne, B., Hafidi, M., Lebrihi, A., Virolle, M. J., \& Ouhdouch, Y. (2008). Screening for rock phosphate solubilizing Actinomycetes from Moroccan phosphate mines. Applied Soil Ecology, 38(1), 12-19.

Hermawan, Budi; Rohman, Fatchur; Rahayu, Mintarti; Salim, U. (2016). Borobudur Temple as Buddhist Pilgrimage Destination in Indonesia: an Analysis of Factors that Affect Visit Intention. Journal of International Buddhist Studies, 7(2), 98-110.

Hop, D. Van, Sakiyama, Y., Thi, C., Binh, T., Otoguro, M., Hang, D. T., Ando, K. (2011). Taxonomic and ecological studies of actinomycetes from $\mathrm{Vi}$ etnam: isolation and genus-level diversity. The Journal of Antibiotics, 64(9), 599-606.

Keshari, N., \& Adhikary, S. P. (2014). Diversity of cyanobacteria on stone monuments and building facades of India and their phylogenetic analysis. International Biodeterioration and Biodegradation, 90, 45-51.

Khan, M. S., Zaidi, A., \& Musarrat, J. (2014). Phosphate solubilizing microorganisms: Principles and application of microphos technology. Phosphate Solubilizing Microorganisms: Principles and Application of Microphos Technology, 1-297.

Kim, O., Cho, Y., Lee, K., Yoon, S., Kim, M., Na, H., ... Chun, J. (2012). Introducing EzTaxon-e: a prokaryotic 16S rRNA gene sequence database with phylotypes that represent uncultured species. International Journal of Systematic and Evolutionary Microbiology, 62, 716-721.

Klymyshin, D. O., Nimets, O. Y., Stefanyshyn, O. M., \& Fedorenko, V. O. (2013). Heterologous expression of the lndYR and wblA gh genes in Streptomyces nogalater LV65, S. echinatus DSM40730, and S. peucetius subsp. Caesius ATCC27952 (producers of anthracycline antibiotics). Cytology and Genetics, 47(4), 197-201.

Kumar, N., Mual, P., Verma, A., Krishnamurthi, S., Mayilraj, S., Kaur, G., \& Kumar, A. (2016). Microbacterium aureliae sp. nov., a novel actinobacterium isolated from Aurelia aurita, the moon jellyfish. International Journal of Systematic and Evolutionary Microbiology, 66(11), 4665-4670.

Li, H., Lan, W., Katayama, Y., Gu, J.-D., \& Wang, W.-D. (2010). Microbial Community Analysis of Fresh and Old Microbial Biofilms on Bayon Temple Sandstone of Angkor Thom, Cambodia. Microbial Ecology, 60(1), 105-115.

Li, Q., Zhang, B., He, Z., \& Yang, X. (2016). Distribution and diversity of bacteria and fungi colonization in stone monuments analyzed by highthroughput sequencing. PLOS ONE, 11(9), 1-17.
Luo, Q., Hu, H., Peng, H., Zhang, X., \& Wang, W. (2015). Isolation and structural identification of two bioactive phenazines from Streptomyces griseoluteus P510. Chinese Journal of Chemical Engineering, 23(4), 699-703.

Michael, G. P., Gandhi, M. R., Pathalam, G., Savarimuthu, I., Appadurai, D. R., Naif, A. A.-D., \& Rajendran, H. A. D. (2017). Isolation and molecular characterization of actinomycetes with antimicrobial and mosquito larvicidal properties. Beni-Suef University Journal of Basic and Applied Sciences, 6(2), 209-217.

Mitsukura, K., Sakamoto, H., Kubo, H., Yoshida, T., \& Nagasawa, T. (2010). Bioconversion of 1adamantanol to 1,3-adamantanediol using Streptomyces sp. SA8 oxidation system. Journal of Bioscience and Bioengineering, 109(6), 550-553.

Palaniappan, P., Chauhan, P. S., Saravanan, V. S., Anandham, R., \& Sa, T. (2010). Isolation and characterization of plant growth promoting endophytic bacterial isolates from root nodule of Lespedeza sp. Biology and Fertility of Soils, 46(8), 807-816.

Pinheiro, A. C., Mesquita, N., Trovão, J., Soares, F., Tiago, I., Coelho, C., Portugal, A. (2018). Limestone biodeterioration: A review on the Portuguese cultural heritage scenario. Journal of Cultural Heritage.

Pittayakhajonwut, P., Tanasupawat, S., Suwanborirux, K., Kudo, T., Supong, K., Thawai, C., \& Suriyachadkun, C. (2012). Micromonospora sediminicola sp. nov., isolated from marine sediment. International Journal of Systematic and Evolutionary Microbiology, 63(Pt 2), 570-575.

Purawijaya, D. A., \& Priyantika, A. G. (2013). Biological Assessment Pertumbuhan Lumut di Candi Borobudur pada Sisi Utara dan Selatan Lorong 2. Jurnal Kons, 7(1), 60-65.

Putri, A. L., Lisdiyanti, P., \& Kusmiati, M. (2018). Identifikasi Aktinomisetes Sedimen Air Tawar Mamasa, Sulawesi Barat Dan Aktivitasnya Sebagai Antibakteri Dan Pelarut Fosfat. Jurnal Bioteknologi \& Biosains Indonesia (JBBI), 5(2), 139148.

Ramirez-Rodriguez, L., Stepanian-Martinez, B., Morales-Gonzalez, M., \& Diaz, L. (2018). Optimization of the Cytotoxic Activity of Three Streptomyces Strains Isolated from Guaviare River Sediments (Colombia, South America) . BioMed Research International, 2018, 1-14.

Saini, A., Aggarwal, N. K., Sharma, A., \& Yadav, A. (2015). Actinomycetes: A Source of Lignocellulolytic Enzymes. Enzyme Research, 2015(June 2016).

Sales, A. N. de, Souza, A. C. de, Moutta, R. de O., Ferreira-Leitão, V. S., Schwan, R. F., Dias, \& Ri- 
beiro, D. (2017). Use of lignocellulose biomass for endoxylanase production by Streptomyces termitum. Preparative Biochemistry and Biotechnology, 47(5), 505-512.

Sharma, S. B., Sayyed, R. Z., Trivedi, M. H., \& Gobi, T. A. (2013). Phosphate solubilizing microbes: Sustainable approach for managing phosphorus deficiency in agricultural soils. SpringerPlus, 2(1), $1-14$.

Tsang, C. C., Xiong, L., Poon, R. W. S., Chen, J. H. K., Leung, K. W., Lam, J. Y. W., Woo, P. C. Y. (2016). Gordonia hongkongensis sp. nov., isolated from blood culture and peritoneal dialysis effluent of patients in Hong Kong. International Journal of Systematic and Evolutionary Microbiology, 66(10), 3942-3950.

Wang, W., Peng, H., Zhang, X., Hui, J., \& Hu, H. (2014). Streptomyces griseoruber Y1B, a Novel Streptomyces for 1-Hydroxyphenazine Production. Journal of Applied Biotechnology, 2(2), 13.

Wibberg, D., Haltli, B., Kalinowski, J., Bandow, J. E., Al-Dilaimi, A., Nowrousian, M., Senges, C. H. R.
(2018). The secreted metabolome of Streptomyces chartreusis and implications for bacterial chemistry . Proceedings of the National Academy of Sciences, 115(10), 201715713.

Xie, Q. Y., Ren, J., Li, L., Li, Y., Deng, Z. X., \& Hong, K. (2016a). Micromonospora mangrovi sp. nov., isolated from mangrove soil. Antonie van Leeuwenhoek, International Journal of General and Molecular Microbiology, 109(4), 483-491.

Xie, Q. Y., Ren, J., Li, L., Li, Y., Deng, Z. X., \& Hong, K. (2016b). Micromonospora maritima sp. nov., isolated from mangrove soil. Antonie van Leeuwenhoek, International Journal of General and Molecular Microbiology, 109(4), 483-491.

Yeager, C. M., Gallegos-Graves, L. V., Dunbar, J., Hesse, C. N., Daligault, H., \& Kuske, C. R. (2017). Polysaccharide degradation capability of Actinomycetales soil isolates from a semiarid grassland of the Colorado Plateau. Applied and Environmental Microbiology, 83(6), 1-19. 